\title{
Stable Iodine Nutrition During Two Decades of Continuous Universal Salt Iodisation in Sri Lanka
}

\author{
Renuka Jayatissa ${ }^{1, *}$, Jonathan Gorstein ${ }^{2}$, Onyebuchi E. Okosieme ${ }^{3}$, John H. Lazarus ${ }^{3}$ and \\ Lakdasa D. Premawardhana ${ }^{3}$ (D) \\ 1 Department of Nutrition, Medical Research Institute, Danister De Silva Mawatha, Colombo 8, Sri Lanka \\ 2 University of Washington, Department of Global Health, Seattle, WA 98195, USA; jgorstein@ign.org \\ 3 Centre for Endocrine and Diabetes Sciences and Thyroid Research Group, C2 Link Corridor, \\ University Hospital of Wales, Heath Park, Cardiff CF14 4XN, UK; Okosiemeoe@cardiff.ac.uk (O.E.O.); \\ Lazarus@cardiff.ac.uk (J.H.L.); PremawadhanaLD@cardiff.ac.uk (L.D.P.) \\ * Correspondence: renukajayatissa@ymail.com; Tel.: +94-777-788-444
}

Received: 23 March 2020; Accepted: 9 April 2020; Published: 16 April 2020

\begin{abstract}
Universal salt iodisation (USI) was introduced in Sri Lanka in 1995. Since then, four national iodine surveys have assessed the iodine nutrition status of the population. We retrospectively reviewed median urine iodine concentration (mUIC) and goitre prevalence in 16,910 schoolchildren (6-12 years) in all nine provinces of Sri Lanka, the mUIC of pregnant women, drinking-water iodine level, and the percentage of households consuming adequately $(15 \mathrm{mg} / \mathrm{kg}$ ) iodised salt (household salt iodine, HHIS). The mUIC of schoolchildren increased from $145.3 \mu \mathrm{g} / \mathrm{L}$ (interquartile range (IQR) $=84.6-240.4)$ in 2000 to $232.5 \mu \mathrm{g} / \mathrm{L}(\mathrm{IQR}=159.3-315.8)$ in 2016 , but stayed within recommended levels. Some regional variability in mUIC was observed (178.8 and $297.3 \mu \mathrm{g} / \mathrm{L}$ in 2016). There was positive association between mUIC in schoolchildren and water iodine concentration. Goitre prevalence to palpation was a significantly reduced from $18.6 \%$ to $2.1 \%(\mathrm{p}<0.05)$. In pregnant women, median UIC increased in each trimester (102.3 (61.7-147.1); 217.5 (115.6-313.0); $273.1(228.9-337.6) \mu \mathrm{g} / \mathrm{L}(\mathrm{p}=0.000)$ ). We conclude that the introduction and maintenance of a continuous and consistent USI programme has been a success in Sri Lanka. In order to sustain the programme, it is important to retain monitoring of iodine status while tracking salt-consumption patterns to adjust the recommended iodine content of edible salt.
\end{abstract}

Keywords: iodine schoolchildren; urine iodine; goitre; iodised salt; water iodine; iodine pregnant women

\section{Introduction}

Iodine is a micronutrient that primarily acts through the thyroid gland and its two hormones (thyroxine and triiodothyronine), and it is vital to the integrity of many physiological functions in the human body [1,2]. Iodine deficiency may affect multiple aspects of human development (including intrauterine physical and neurological development), linear growth, and physiological organ function. Organs such as the brain and nervous system are particularly vulnerable in their formative stages during intrauterine life [1,2]. Fortunately, iodine deficiency is relatively easy and inexpensive to prevent through universal iodisation of all edible salt. This is a pure food-chain effect, beginning with soil erosion and leading to environmental iodine deficiency, and a lack of iodine sources in our typical diet. Iodised salt was first introduced in Switzerland in $1922[2,3]$ and has been used in many previously iodine-deficient countries with good results [4]. The restoration of iodine sufficiency in many of these countries has been a major public-health triumph facilitated by the United Nations Children's Fund (UNICEF), World Health Organisation (WHO), and International Council of Control 
Iodine Deficiency Disorders (ICCIDD, now named Iodine Global Network (IGN)). Statutory regulations enforcing universal salt iodisation (USI) were implemented by regulatory authorities in each country [5]. Sri Lanka is one such country that has successfully adopted a USI programme since 1995.

\section{History of Iodine Deficiency and Its Management in Sri Lanka}

Bennet and Pridham first referred to the existence of endemic goitre along the coast of Galle in the southern province of Sri Lanka in 1849 [6]. However, the link between poor iodine consumption and endemic goitre was first recognised only in the 20th century in a WHO study that confirmed high goitre rates, an iodine-poor diet, and low iodine concentrations in drinking water in 1950 [7]. Mahadeva and his group in 1960 identified a "goitre belt" extending across the western, central, southern, sabaragamuwa, and uva provinces in Sri Lanka [8]. The high annual rainfall in these regions led experts to believe that iodine was "leeched" from the soil, leading to iodine deficiency. At that stage, almost no goitre had been identified in the northern, eastern, and north-western provinces [9]. However, in 1986, Fernando et al. described a high goitre rate of $18.8 \%$ in schoolchildren in 17 of 24 districts in Sri Lanka-a variable prevalence of $6.5 \%$ in the Matale district and $30.2 \%$ in the Kalutara district [10]. This study used palpation as the method of goitre assessment, and was the first to recognise iodine deficiency as a major public-health problem.

USI was introduced nationwide by the government in 1995 by statutory regulation [11]. This legislation banned the sale of non-iodised salt for human consumption, thus ensuring access to iodised salt to all consumers in the country. Potassium iodate was used as the vehicle of iodine supplementation, and added to salt at an optimal concentration of $50 \mathrm{ppm}$ at producer level and 25 ppm at consumer level. The national reference laboratory for monitoring USI was established at the Medical Research Institute (MRI) in 2000 with the aid of UNICEF. This laboratory has the dual role of monitoring USI and of assessing its clinical impact by performing periodic national iodine surveys (NISs). External quality control is linked to the EQUIP programme of the Centers for Disease Control (CDC), Atlanta, Georgia, USA [12].

We review and describe the iodine-nutrition status in Sri Lanka by utilising serial datasets from the four national iodine surveys carried out by the MRI between 2000 and 2016. We assessed the success of USI in Sri Lanka in relation to global indicators of population iodine status, i.e., median urine iodine concentration (mUIC), total goitre prevalence rates (TGRs), and household salt iodine (HHIS) consumption.

\section{Methods}

\subsection{Available Data Sources for Analysis}

mUIC, TGRs, and HHIS were available for analysis from 4 national iodine surveys (NISs) between 2000 and 2016-NIS2000, NIS2005, NIS2010, and NIS2016 [13-16]. These NIS used a two-stage stratified cluster-sampling technique as specified by the WHO, UNICEF, and IGN $[17,18]$. During each NIS, the same team of field investigators visited all nine administrative provinces of the country to detect goitres by palpation, and collected urine from 6-12-year-old schoolchildren, and salt from their households and drinking-water samples from the household or school locality. Figure 1 illustrates the map of Sri Lanka demarcating 9 provinces. All four national studies were carried out to ascertain provincial variation. A total of 16,910 schoolchildren of 6-12 years of age were studied in the four surveys and included in the final analysis (Table 1). Furthermore, we had available data for analysis from the national micronutrient study in pregnant women in 2015 (MNSPM2015) (Table 2) [19]. 


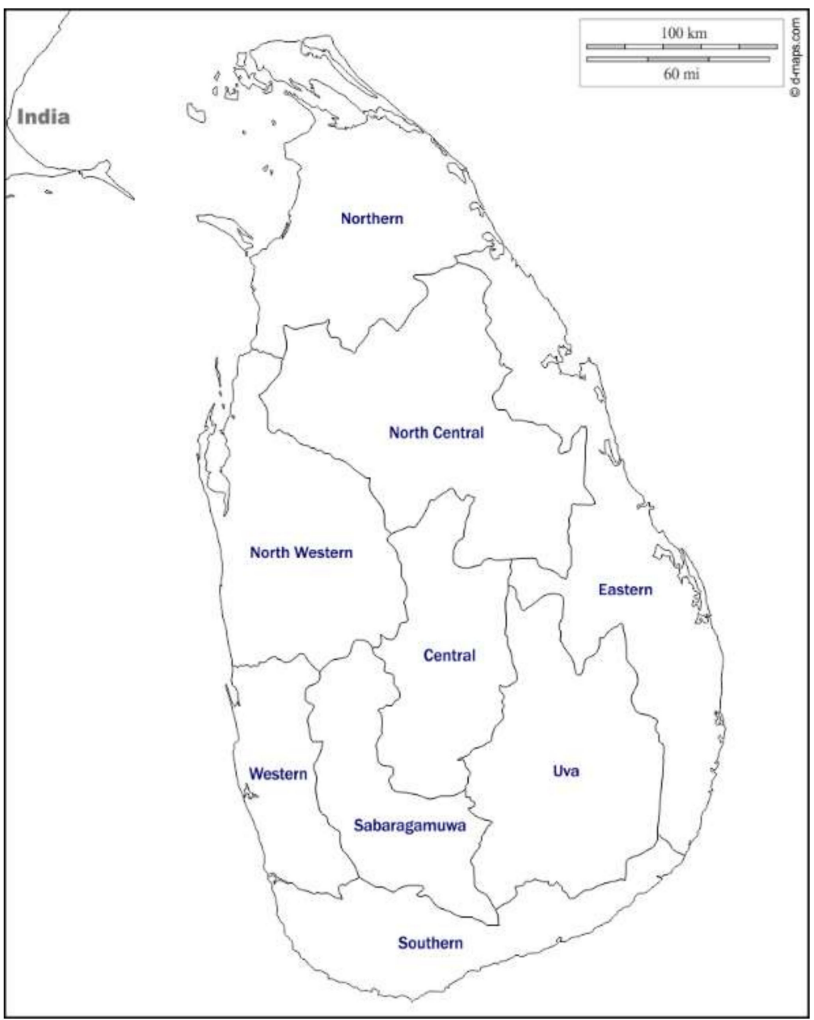

Figure 1. Map of Sri Lanka demarcating nine provinces.

Table 1. Median urine iodine concentration (mUIC), goitre prevalence, and household salt iodine consumption in schoolchildren aged 6-12 years in 2000-2016. TGR, total goitre prevalence rate; HHIS, household salt iodine; IQR, interquartile range.

\begin{tabular}{|c|c|c|c|c|c|c|c|}
\hline \multirow[t]{2}{*}{ Surveys } & \multicolumn{2}{|c|}{ UIC $(\mu \mathrm{g} / \mathrm{L})$} & \multirow{2}{*}{$\begin{array}{c}\text { TGR }^{3} \\
\%\end{array}$} & \multicolumn{4}{|c|}{ HHIS (\%) ${ }^{4}$} \\
\hline & $\%<50^{1}$ & Median (IQR) $^{2}$ & & $<5$ & $5-14.9$ & $15-30$ & $>30$ \\
\hline $\begin{array}{l}\text { NIS-2016 } \\
(\mathrm{n}=5000)\end{array}$ & 1.6 & $\begin{array}{c}232.5 \\
(159.3-315.8)\end{array}$ & 1.9 & 3.1 & 18.4 & 63.5 & 15.0 \\
\hline $\begin{array}{l}\text { NIS-2010 } \\
(\mathrm{n}=7401)\end{array}$ & 6.7 & $\begin{array}{c}163.4 \\
(99.1-245.1)\end{array}$ & 4.4 & 4.6 & 27.1 & 52.5 & 16.1 \\
\hline $\begin{array}{l}\text { NIS-2005 } \\
(\mathrm{n}=1879)\end{array}$ & 7.4 & $\begin{array}{c}154.4 \\
(90.3-252.6)\end{array}$ & 3.8 & 0.0 & 8.7 & 47.7 & 43.5 \\
\hline $\begin{array}{l}\text { NIS-2000 } \\
(\mathrm{n}=2628)\end{array}$ & 2.7 & $\begin{array}{c}145.3 \\
(84.6-315.8)\end{array}$ & 18.0 & - & - & - & - \\
\hline
\end{tabular}

Table 2. Median UIC in pregnant women in three trimesters (national micronutrient study in pregnant women in 2015, NNMSPM2015).

\begin{tabular}{|c|c|c|c|}
\hline \multirow{2}{*}{$\begin{array}{c}\text { Trimesters } \\
\text { Period of Amenorrhea (POA) }\end{array}$} & \multicolumn{2}{|c|}{ UIC $(\mu \mathrm{g} / \mathrm{L})$} & \multirow[t]{2}{*}{ No } \\
\hline & $\%<50^{1}$ & Median (IQR) $^{2}$ & \\
\hline $\begin{array}{c}\text { First trimester } \\
(\leq 12 \text { weeks of POA })\end{array}$ & 17.0 & $102.3(61.7-147.1)$ & 447 \\
\hline $\begin{array}{l}\text { Second trimester } \\
\text { (13-28 weeks of POA) }\end{array}$ & 6.2 & $\begin{array}{c}217.5 \\
(115.6-313.0)\end{array}$ & 339 \\
\hline $\begin{array}{l}\text { Third trimester } \\
(>28 \text { weeks of POA) }\end{array}$ & 0.0 & $\begin{array}{c}273.1 \\
(228.9-337.6)\end{array}$ & 176 \\
\hline Overall & 10.1 & $157.7(91.2-256.4)$ & 962 \\
\hline
\end{tabular}




\subsection{Indicators of Population Iodine Status}

Three primary indicators of population iodine status were considered, and we used the methodology described below to assess the outcomes of the USI programme: (i) mUIC was measured by ammonium persulfate digestion with spectrophotometric detection of the Sandell-Kolthoff reaction in a laboratory certified by the EQUIP programme [20-22]; (ii) TGR - the grading of goitres was done by palpation by the same team utilising the classification recommended by the WHO, UNICEF, and IGN [3,18]: (a) "no goitre" - thyroid not palpable or visible; (b) "goitre present" - thyroid palpable not visible or palpable and visible; and (iii) iodine content in salt: titration method to measure the iodine content of salt certified by a regional iodine laboratory $[3,18]$. Geographical location (province), iodine in drinking water, and household salt were measured to estimate their influence on optimal iodine consumption. Iodine levels in drinking water at the household level and school localities were tested using ammonium persulfate oxidation [20].

\section{Data Analysis}

The following definitions were used for classifying population iodine nutrition status [22]. (i) Median UIC: (a) adequate mUIC-150-299 $\mu \mathrm{g} / \mathrm{L}$ (pregnant women) and 100-299 $\mu \mathrm{g} / \mathrm{L}$ (schoolchildren); (b) excessive mUIC $-\geq 300 \mu \mathrm{g} / \mathrm{L}$; and (c) iodine sufficiency $-<20 \%$ samples should have mUIC of $<50 \mu \mathrm{g} / \mathrm{L}$. (ii) Household salt iodine (HHIS) content: we classified salt iodine content as follows. (a) $<5 \mathrm{mg} / \mathrm{kg}$ —non-iodised; (b) 5-14.9 mg/kg—inadequately iodised; (c) 15-30 mg/kg—adequately iodised; and (d) $>30 \mathrm{mg} / \mathrm{kg}$-over-iodised. (iii) Iodine content in drinking water: iodine in drinking water was classified as follows. (a) $<5 \mathrm{mg} / \mathrm{kg}$-no iodine; (b) $5-14.9 \mathrm{mg} / \mathrm{kg}$-low iodine; (c) $15-30 \mathrm{mg} / \mathrm{kg}$ —-moderate iodine; and (d) $>30 \mathrm{mg} / \mathrm{kg}$ - high iodine [23,24].

Statistical analysis was performed using SPSS (IBM version 24). Data that were not normally distributed were expressed as median and interquartile range (IQR) unless otherwise stated. The Mann-Whitney U-test was used to compare data between the two groups. The Kruskal-Wallis test (nonparametric analysis of variance (ANOVA)) was used to assess the significance of differences between more than two groups. Categorical variables were analysed using the chi-squared test for trend; a p-value of $<0.05$ was considered statistically significant.

\section{Results}

(i) mUIC was consistently in the adequate or iodine-sufficient range in all four national iodine surveys of 2000-2016. There has been a significant increase in mUIC, but still within the adequate range in surveys between 2000 (145.3 (84.6-240.4)) and 2016 (232.5 (159.3-315.8)); $p=0.000)$. There has also been a significant reduction in the percentage of schoolchildren with mUIC $<50 \mu \mathrm{g} / \mathrm{L}(2.7 \%$ in 2000 vs $1.6 \%$ in 2016; $p=0.000$ ). As shown in Table 2, the mUIC of pregnant women was also in the adequate or iodine-sufficient range $(157.7(228.9-337.6) \mu \mathrm{g} / \mathrm{L})$ at the national level, and in the second and third trimesters 217.5 (115.6-313.0), and 273.1 (228.9-337.6) $\mu \mathrm{g} / \mathrm{L} ; \mathrm{p}<0.000)$. Table 3 shows there is regional variability in mUIC levels in children of 6-12 years of age (297.3 vs. $178.8 \mu \mathrm{g} / \mathrm{L}$ in 2016; $p=0.000$ ). It was significantly higher in the northern and north-central provinces when compared to the rest of the country since 2005 . 
Table 3. Regional variations of key indicators of population iodine nutrition in 2000-2016.

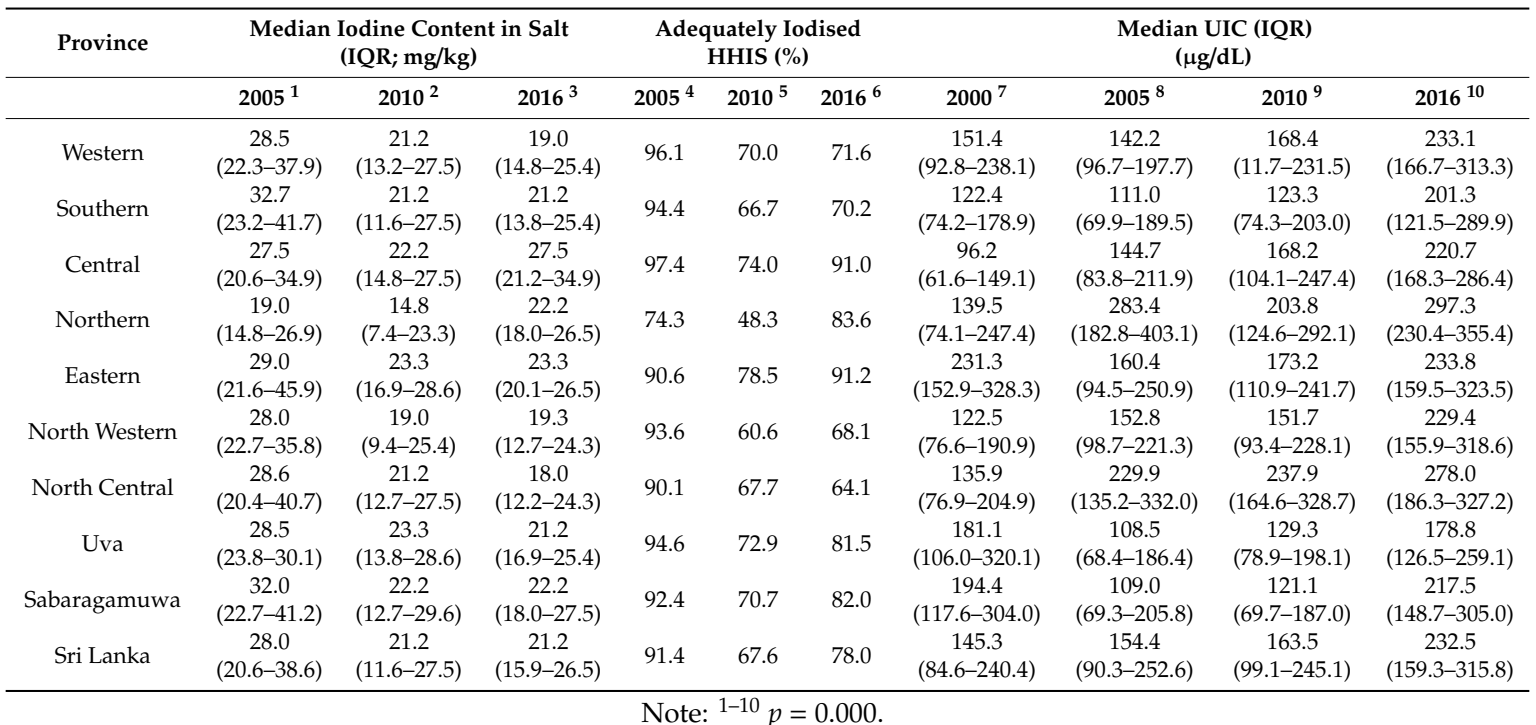

(ii) There was significant reduction in TGR by palpation between surveys done in $2000(18.0 \%)$ and $2016(1.9 \%$; $p=0.000$; Table 1$)$.

(iii) The iodine content of HHIS was only measured since 2005, and since that time, over $95 \%$ of all HHIS has contained at least some iodine $(>5 \mathrm{mg} / \mathrm{kg})$. The percentage of HHIS with adequate iodine concentrations (defined as $15-30 \mathrm{mg} / \mathrm{kg}$ ) showed a significant increase- $47.7 \%$ in NIS2005 vs. $63.5 \%$ in NIS2016 ( $p=0.000)$. Furthermore, only $3.1 \%$ had a salt content of $<5 \mathrm{mg} / \mathrm{kg}$ (non-iodised) in the last survey in 2016. The prevalence of over-iodised salt $(>30 \mathrm{mg} / \mathrm{kg}$ ) significantly fell from $43.5 \%$ in 2005 to $15.0 \%$ in 2016 ( $p=0.000$; Table 1). HHIS was less than $90 \%$ at the national level, and in all provinces in 2010 and 2016 except for the central and eastern provinces. In 2016, the interprovincial difference of median iodine content in HHIS was between 18.0 and $27.5 \mathrm{mg} / \mathrm{kg}$ (Table 3).

(iv) Median iodine content of drinking water was $33.4(12.3-66.8) \mu \mathrm{g} / \mathrm{L}$. Wide variation was observed between provinces $(8.3(4.6-29.0)$ vs $75.5(48.4-102.5) \mu \mathrm{g} / \mathrm{L} ; p=0.000)$ in the uva and north-central provinces, respectively (Table 4$)$.

Table 4. Regional variations of median iodine content of drinking water in 2016.

\begin{tabular}{ccc}
\hline Province & No & Median (IQR) $\mu \mathrm{g} / \mathrm{L}$ \\
\hline Western & 67 & $15.6(4.1-29.1)$ \\
Southern & 70 & $19.1(15.3-29.9)$ \\
Central & 68 & $18.0(5.7-44.6)$ \\
Northern & 78 & $53.4(28.9-79.4)$ \\
Eastern & 189 & $33.3(17.0-69.6)$ \\
North Western & 122 & $39.9(9.4-61.4)$ \\
North Central & 170 & $75.5(48.4-102.5)$ \\
Uva & 62 & $8.3(4.6-50.4)$ \\
Sabaragamuwa & 108 & $31.3(15.1-50.4)$ \\
Sri Lanka & 934 & $33.4(12.3-66.8)$ \\
\hline \multicolumn{3}{c}{ Note: $p=0.000}$.
\end{tabular}

Figure 2 provides a graphical representation of the data on median UIC of children aged 6-12 years in 2016, stratified by the iodine content in HHIS and in drinking water. These data are noteworthy since the mUIC was within the optimal range in all subgroups, including those households of which the iodine content in HHIS was $<5 \mathrm{ppm}$ or in the range of 5-14.9 ppm, suggesting that the consumed 
iodine in HHIS is not the exclusive diet source of iodine. There was a significant increase in median UIC with increasing iodine concentrations in drinking water $(p=0.000)$.

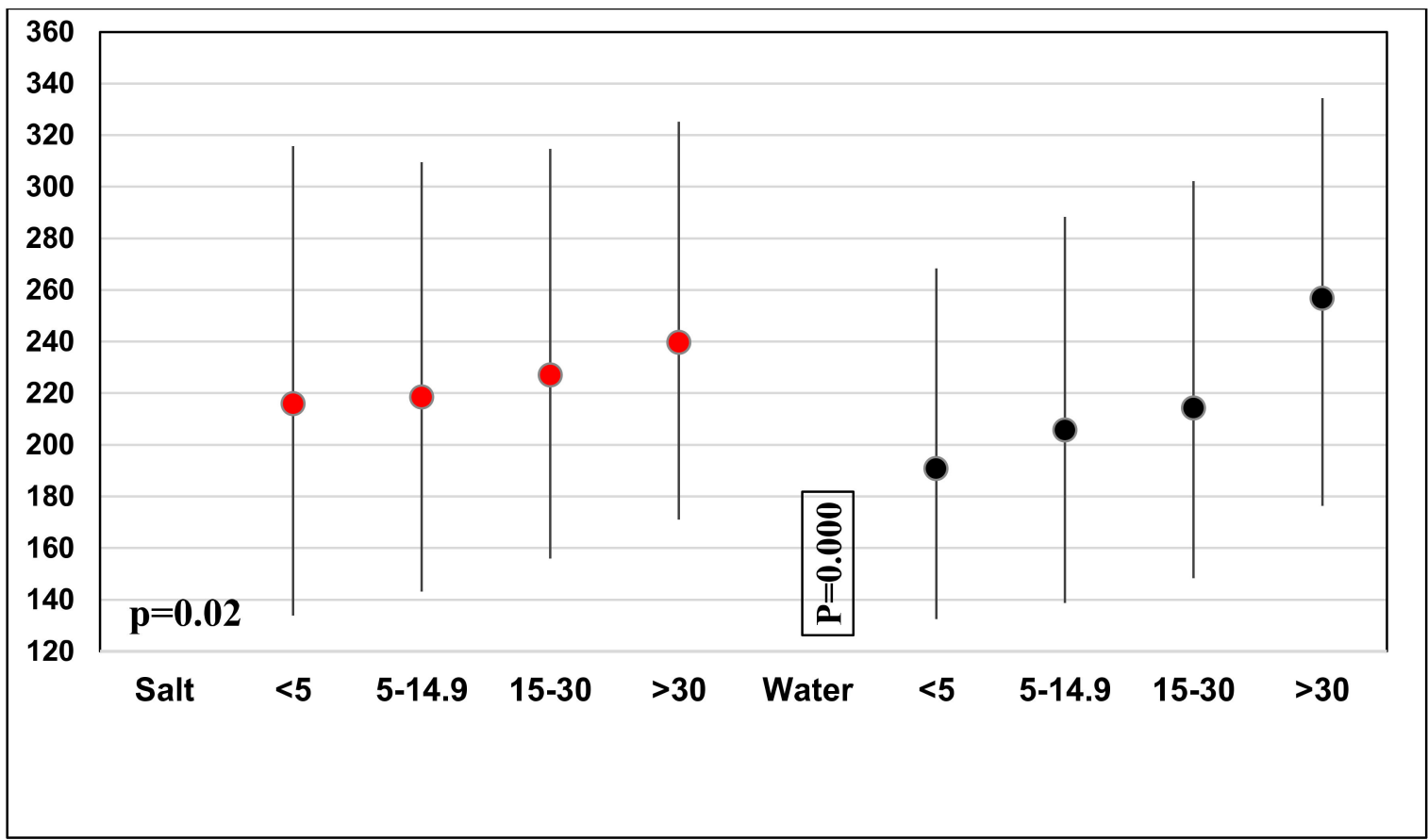

Figure 2. Median urine iodine concentration (IQR) and its relationship with iodine concentrations in household salt and drinking water in school children aged 6-12 years in 2016.

\section{Discussion}

USI was first implemented in Sri Lanka in 1995. We demonstrated in this retrospective review of data from four national iodine surveys of over more than two decades of continuous salt iodisation that (i) mUIC has consistently been in the adequate range with a sequential increase within safe and recommended limits; (ii) the goitre-prevalence rate to palpation in children between 6-12 years significantly decreased between 2000 and 2016 (18.0\% to 1.9\%; $p=0.000)$; and (iii) the percentage of adequately iodised household salt samples significantly increased during this period (47.7\% in 2005 vs. $63.3 \%$ in 2016; $p=0.000$ ), and its household consumption remains satisfactory (Tables 1 and 3).

These indices of population iodine nutrition favourably reflect the success of the USI programme enforced by successive governments of Sri Lanka, having adequate iodine status at the national level and in most provinces (Tables 1 and 3). Furthermore, there has been a recurrence of iodine deficiency in several countries where iodine-deficiency disorders (IDDs) were eliminated with USI because of inadequate monitoring of their USI programmes [25-29]. Strict monitoring is essential in sustaining proper iodine nutrition in countries that adopt USI [28].

However, there is a need for caution. (a) The median UIC of pregnant women is only marginally above the recommended cut off of $150 \mu \mathrm{g} / \mathrm{L}$, and iodine-insufficient in the first trimester (102.3 (61.7-147.1) $\mu \mathrm{g} / \mathrm{L}$ (Table 2)). There was a remarkable improvement in the iodine status of pregnant women compared to $2011(113.7 \mu \mathrm{g} / \mathrm{L})$ [30]. There was also a significant minority of pregnant women (nearly $10 \%$ ) who had a median UIC of $<50 \mu \mathrm{g} / \mathrm{L}$. This is an important population group, and inadequate iodine delivery to this group may have important long-term consequences, particularly regarding the intrauterine development of the brain, central nervous system, and physical growth [29]. (b) The median UIC of schoolchildren in the northern and north-central provinces in 2016 approached $300 \mu \mathrm{g} / \mathrm{L}$. In these two areas at risk of iodine excess, iodine content in drinking water was the highest among those provinces (Table 4). Other countries' experience with high iodine content in drinking water should be reviewed $[31,32]$. (c) Some regional variability in mUIC was observed over the course 
of the programme, but in the most recent survey, the range was between 178.8 and $297.3 \mu \mathrm{g} / \mathrm{L}$, all within the optimal range. The reasons for regional variability of median UIC have not been investigated in detail, but need to be noted (Table 2). There is a clear need, therefore, to closely monitor these groups in the future, with periodic well-designed and more elaborate studies. However, we acknowledge that these UIC assessments were done on single "spot" samples of urine and may not be truly representative of the iodine-nutrition status of each individual in these communities [28].

We also showed that the supervision and monitoring of salt iodisation has improved over two decades of USI. The percentage of samples delivering adequate levels of salt at the consumer level (i.e., $15-30 \mathrm{mg} / \mathrm{kg}$ ) increased from $47.5 \%$ in NIS2005 to $63.3 \%$ in NIS2016 $(p=0.000)$, while at the same time, the percentage of over-iodised salt samples has significantly decreased $(p=0.000$; Table 1$)$. The percentage of households using adequately iodised salt was less than $90 \%$ (the WHO goal for USI) at the national level and in seven out of nine provinces (Table 3). However, it showed that the median HHIS content in provinces was between 18.0 and $27.5 \mathrm{mg} / \mathrm{kg}$, confirming that household iodised salt was providing a significant amount of iodine to the diet [33].

Despite a $<90 \%$ of households consuming adequately iodised salt, there has been an increase in mUIC, and some provinces in the country consistently showed a high level of mUIC. Daily mean per capita salt intake of Sri Lankans was reported as $8.3 \mathrm{~g}$ (CI: 7.9, 8.8) in 2012 [34]. We also need to be aware of the contribution of other sources of iodine contributing to population iodine nutrition, e.g., drinking water, processed foods, or condiments, which are being manufactured with iodised salt, as well as some iodine in foods. Our results indicated a positive association between iodine status in schoolchildren and water iodine concentration, although the major contributor to iodine intake is iodised salt in the diet (Figure 2). In fact, over $95 \%$ of households have consistently had access to iodised salt since 2005. A similar contribution was observed in other countries [24,32]. There is a need to adjust the recommended level of HHIS, and to explore the iodine supply through different dietary sources and the geological assessment of soil iodine content for future monitoring.

IGN/UNICEF recommends that the optimal iodine intake, as measured by the median UIC for school-age children, should be $<300 \mu \mathrm{g} / \mathrm{L}$, while the mUIC among pregnant women should be $<500 \mu \mathrm{g} / \mathrm{L}$ [22]. Thus, the current salt-iodisation programme is having its desired impact and not placing the Sri Lankan population at risk for iodine excess, as described in the previous study [33]. The salt-iodisation programme needs to be consistently monitored so that the level of iodine in all edible salt, including that used at the household level as well as in processed foods and condiments, leads to an optimal intake. As salt-reduction efforts are implemented, there may be a decline in overall salt consumption, in which case the government may need to accordingly adjust the recommended salt iodine level to ensure that public-health strategies of iodine-deficiency prevention, salt reduction, and reduction in NCDs are realised.

Despite adequate iodine nutrition among schoolchildren, iodine nutrition among pregnant women remains just above the cut-off levels in the country. There is a need to focus on pregnant women for continuous monitoring while sustaining the iodised-salt programme.

This study has several strengths. (a) Data availability from a large number of 6-12-year-old schoolchildren (16,910 in total); (b) uniform methodology for UIC assessments over the period of review in a single laboratory with stringent external quality control; (c) permanent health staff used as a single team in all four studies and goitre palpation; (d) minimising variability in urine- and salt-assay methodology using the same protocols developed by the UNICEF, WHO, and IGN. However, the unavailability of pre-USI data for comparison was an inherent shortcoming of this study.

\section{Conclusions}

The iodine nutrition of the population has remained optimal and stable in Sri Lanka during more than two decades of continuous salt iodisation after its introduction in 1995. However, we recommend the close and careful monitoring of pregnant women and schoolchildren in view of the data we presented. 
The delivery of salt to consumers has improved and is adequate in the majority. The contribution of dietary sources other than salt needs to be assessed in well-planned studies.

Author Contributions: R.J. analysed datasets; R.J., J.G., L.D.P., J.H.L., and O.E.O. conceptualised, designed, and wrote the paper. All authors read the manuscript, made a substantial contribution to the revision, and approved the final manuscript. All authors have read and agreed to the published version of the manuscript.

Acknowledgments: We thank the staff of the Department of Nutrition, Medical Research Institute, Ministry of Health, Sri Lanka for conducting the national survey, and all the participants of the study. We would like to thank Dulitha Fernando, Pierre Boudex, and the late Meliyanthi Gunathilaka for supporting us in every step. Adikari, Morina Hossein, Aberra Bekele, Moazzem Hossaine from UNICEF, Colombo and Chandrakant Pandav for all their support from the beginning. This research received no specific grant from any funding agency in the public, commercial, or not-for-profit sectors.

Conflicts of Interest: The opinions expressed are those of the authors and do not necessarily reflect the views of the institutions with which they are affiliated. The authors declare that there is no conflict of interest.

\section{References}

1. Stanbury, J.B.; Hetzel, B.S. Endemic Goitre and Endemic Cretinism, Iodine Nutrition in Health and Disease; John Wiley and Sons: New York, NY, USA, 1980.

2. World Health Organization. Iodine and Health-Eliminating Iodine Deficiency Disorders Safely through Salt Iodisation; A statement by the WHO; WHO: Geneva, Switzerland, 1994.

3. World Health Organization. Assessment of Iodine Deficiency Disorders and Monitoring Their Elimination: A Guide for Programme Managers, 3rd ed.; WHO: Geneva, Switzerland, 2007.

4. Iodine Global Network (IGN). Global Scorecard of Iodine Nutrition in 2019. Available online: https: //www.ign.org/cm_data/Global_Scorecard_2019_SAC.pdf (accessed on 14 March 2020).

5. World Health Organization. Recommended Iodine Levels in Salt and Guidelines for Monitoring their Adequacy and Effectiveness. Based on a Joint WHO/UNICEF/ICCIDD Consultation. World Health Organization: Geneva, Switzerland, 8-9 July 1996. Available online: https://apps.who.int/iris/bitstream/ handle/10665/63322/WHO_NUT_96.13.pdf (accessed on 14 March 2020).

6. Greenwald, I. Some notes on the history of goitre in Ceylon. Ceylon Med J. 1953, 2, 140. [PubMed]

7. Wilson, D.C. Goitre in Ceylon and Nigeria. Br. J. Nutr. 1954, 8, 90-99. [CrossRef] [PubMed]

8. Mahadeva, K.; Seneviratne, D.A.; Jayatilleke, D.B.; Shanmuganathan, S.S.; Premachandra, P.; Nagarajah, M. Further studies on the problem of goitre in Ceylon. Br. J. Nutr. 1968, 22, 527-534. [CrossRef] [PubMed]

9. Deo, M.G.; Subramanian, T.A.V. Iodine metabolism in children and women with goitre in Ceylon. Br. J. Nutr. 1971, 25, 97-105. [CrossRef] [PubMed]

10. Fernando, M.A.; Balsuriya, S.; Herath, K.B.; Katugampola, S. Endemic Goitre in Sri Lanka. Asia Pac. J. Public Health 1989, 3, 11-18. [CrossRef] [PubMed]

11. Government of Sri Lanka. Food (Iodization of Salt) Regulations under Section 32 of the Food Act, No. 26 of 1980; Department of Government Printing: Colombo, Sri Lanka, 1995.

12. Centers for Diseases Control and Prevention (CDC). The Challenge of Iodine Deficiency Disorders. EQIP 10 Years Anniversary. Atlanta, USA. 2011. Available online: https://www.cdc.gov/labstandards/pdf/equip/ EQUIP_Booklet.pdf (accessed on 14 March 2020).

13. Jayatissa, R.; Gunathilaka, M.; Fernando, D. Iodine nutrition status among schoolchildren after salt iodisation. Ceylon Med. J. 2005, 50, 144-148. [CrossRef] [PubMed]

14. Jayatissa, R.; Gunathilaka, M.; Fernando, D. Second National Iodine Survey; Medical Research Institute: Colombo, Sri Lanka, 2006. Available online: http://www.mri.gov.lk/assets/Nutrition/2005-Second-NationalIDD-Survey-.pdf (accessed on 21 March 2020).

15. Jayatissa, R.; Gunathilaka, M.; Fernando, D. Third National Iodine Survey; Medical Research Institute: Colombo, Sri Lanka, 2010. Available online: https://www.ign.org/cm_data/2017_Sri_Lanka.pdf (accessed on 21 March 2020).

16. Jayatissa, R.; Fernando, D.; De Silva, H. Fourth National Iodine Survey; Medical Research Institute: Colombo, Sri Lanka, 2016. Available online: http://www.mri.gov.lk/assets/Nutrition/2016-Fourth-National-IDD-survey.pdf (accessed on 21 March 2020). 
17. Gorstein, J.S.K.; Parvanta, I.; Begin, I. Indicators and Methods for Cross-Sectional Surveys of Vitamin and Mineral Status of Populations; The Micronutrient Initiative: Ottawa, ON, Canada; Center of Disease Surveillance: Atlanta, GA, USA, 2007.

18. World Health Organisation. Indicators for Assessing Iodine Deficiency Disorders and their Control through Salt Iodizaton; WHO/NUT/94.6; WHO; UNICEF; ICCIDD: Geneva, Switzerland, 1994; pp. 1-55.

19. Jayatissa, R.; Fernando, D.; De Silva, H. National Nutrition and Micronutrient Survey of Pregnant Women in Sri Lanka: 2015; Medical Research Institute/UNICEF/WFP: Colombo, Sri Lanka, 2017. Available online: https://www.wfp.org/publications/national-nutrition-and-micronutrient-survey-pregnant-womensri-lanka (accessed on 21 March 2020).

20. Ohashi, T.; Yamaki, M.; Pandav, C.S.; Karmarkar, M.G.; Irie, M. Simple microplate method for determination of urinary iodine. Clin. Chem. 2000, 46, 529-536. [CrossRef] [PubMed]

21. Delange, F.; de Benoist, B.; Burgi, H.; ICCIDD Working Group. At what median urinary iodine concentration is a population iodine suffcient? IDD News Lett. 2001, 17, 10-11.

22. United Nation of Independent Children's Fund (UNICEF). Guidance on the Monitoring of Salt Iodization Programmes and Determination of Population Iodine Status; UNICEF: New York, NY, USA, 2019.

23. World Health Organization. Iodine in Drinking Water; WHO: Geneva, Switzerland, 2003.

24. Lv, S.; Wang, Y.; Xu, D.; Rutherford, S.; Chong, Z.; Du, Y.; Jia, L.; Zhao, J. Drinking water contributes to excessive iodine intake among children in Hebei, China. Eur. J. Clin. Nutr. 2013, 67, 961-965. [CrossRef] [PubMed]

25. Markou, K.B.; Georgopoulos, A.; Makri, M.; Anastasiou, E.; Vlasopoulou, B.; Lazarou, N.; Veizis, A.; Sakellaropoulos, G.; Vagenakis, A.G. Iodine deficiency in Azerbaijan after the discontinuation of an iodine prophylaxis program: Reassessment of iodine intake and goiter prevalence in schoolchildren. Thyroid 2001, 11, 1141-1146. [CrossRef] [PubMed]

26. Li, M.; Ma, G.; Boyages, S.C.; Eastman, C.J. Re-emergence of iodine deficiency in Australia. Asia Pac. J. Clin. Nutr. 2001, 10, 200-203. [CrossRef] [PubMed]

27. Zimmermann, M.B.; Wegmüller, R.; Zeder, C.; Torresani, T.; Chaouki, N. Rapid relapse of thyroid dysfunction and goiter in school age children after withdrawal of salt iodization. Am. J. Clin. Nutr. 2004, 79, 642-645. [CrossRef] [PubMed]

28. Zimmermann, M.B. Assessing iodine status and monitoring progress of iodised salt programs. J. Nutr. 2004, 134, 1673-1677. [CrossRef] [PubMed]

29. Lazarus, J.H.; Bestwick, J.P.; Channon, S.; Paradice, R.; Maina, A.; Rees, R.; Chiusano, E.; John, R.; Guaraldo, V.; George, L.M. Antenatal thyroid screening and childhood cognitive function. N. Engl. J. Med. 2012, 366, 493-501. [CrossRef]

30. Jayatissa, R.; Gunathilaka, M.M.; Ranbanda, J.M.; Peiris, P.; Jayasingha, J.; Ekanayaka, P.; Kulathunga, H. Iodine status of pregnant women in Sri Lanka. Sri Lanka J. Diabetes Endocrinol. Metab. 2013, 3, 4-7. [CrossRef]

31. Zimmermann, M.B.; Ito, Y.; Hess, S.Y.; Fujieda, K.; Molinari, L. High thyroid volume in children with excess dietary iodine intakes. Am. J. Clin. Nutr. 2005, 81, 840-844. [CrossRef]

32. Shen, H.; Liu, S.; Sun, D.; Zhang, S.; Su, X.; Shen, Y.; Han, H. Geographical distribution of drinking water with high iodine level and association between high iodine level in drinking water and goitre: A Chines national investigation. Br. J. Nutr. 2011, 106, 243-247. [CrossRef] [PubMed]

33. Jayatissa, R.; Fernando, D.N. Supplementation of micronutrients in children and food fortification initiatives in Sri Lanka: Benefits versus risks. Ann. N. Y. Acad. Sci. 2018, 1-14. [CrossRef] [PubMed]

34. Jayatissa, R.; Yamori, Y.; De Silva, A.H.; Mori, M.; De Silva, P.C. Estimation of salt intake, potassium intake and sodium-to-potassium ratio by 24-hour urinary excretion: An urban rural study in Sri Lanka. 2012, in press. [CrossRef]

(C) 2020 by the authors. Licensee MDPI, Basel, Switzerland. This article is an open access article distributed under the terms and conditions of the Creative Commons Attribution (CC BY) license (http://creativecommons.org/licenses/by/4.0/). 